\title{
A pertrochanter törés okozta éves epidemiológiai és egészségbiztosítási betegségteher elemzése Magyarországon
}

\author{
Gazsó Tibor ${ }^{1,2}$ - Elmer Diána ${ }^{1,3}$ - Endrei Dóra dr. ${ }^{1,3}$ - Sebestyén Andor dr. ${ }^{1,3}$ \\ Kajos Luca Fanni ${ }^{1}$. Wiegand Norbert dr. ${ }^{4}$ - Boncz Imre dr. ${ }^{1,3}$ \\ ${ }^{1}$ Pécsi Tudományegyetem, Egészségtudományi Kar, Egészségbiztosítási Intézet, Pécs \\ ${ }^{2}$ Pécsi Tudományegyetem, Kancellária, Egészségügyi Gazdálkodási Igazgatóság, Pécs \\ ${ }^{3}$ Pécsi Tudományegyetem, Egészségtudományi Kar, \\ Real World \& Big Data Egészség-gazdaságtani Kutatóközpont, Pécs \\ ${ }^{4}$ Pécsi Tudományegyetem, Általános Orvostudományi Kar, Klinikai Központ, \\ Traumatológiai és Kézsebészeti Klinika, Pécs
}

\begin{abstract}
Bevezetés: A pertrochanter töréssel kapcsolatos szolgáltatások igénybevétele jelentős terhet jelent a társadalom és az egészségügyi rendszerek számára.

Célkitüzés: Elemzésünk célja volt a pertrochanter törés okozta éves epidemiológiai és egészségbiztosítási betegségteher meghatározása Magyarországon.

Adatok és módszerek: A felhasznált adatok a Nemzeti Egészségbiztosítási Alapkezelő (NEAK) finanszírozási adatbázisából származnak 2018. évre vonatkozóan. A betegszámok alapján meghatároztuk a 100000 lakosra jutó prevalenciát, az éves egészségbiztosítási kiadásokat korcsoportos és nemenkénti bontásban. Az elemzésbe az érintett egészségbiztosítási ellátások teljes körét bevontuk. A pertrochanter töréseket a Betegségek Nemzetközi Osztályozása (BNO, 10. revízió) szerinti S7210-es kóddal azonosítottuk.

Eredmények: A legnagyobb országos betegszámot a járóbeteg-szakellátás esetében találtuk: 2845 férfi, 6312 nő, együtt 9157 fó. Ezt követte az aktívfekvőbeteg-szakellátás (2388 férfi és 5858 nő, együtt 8246 fő). A valamennyi életkorra számított, 100000 lakosra vetített prevalencia a férfiaknál 51,1 beteg, a nóknél 114,7 beteg, együtt 84,3 beteg volt az aktívfekvőbeteg-szakellátásban. A pertrochanter törés kezelésére 7,329 milliárd Ft-ot költöttek 2018-ban (27,12 millió USD, illetve 22,98 millió EUR). A kiadások 28,0\%-a férfiaknál, 72,0\%-a nőknél jelent meg. Az egészségbiztosítási kiadások 90,7\%-a az aktívfekvőbeteg-szakellátásban jelentkezett. Az egy betegre jutó átlagos éves összesített egészségbiztosítási kiadás 858710 Ft (3177 USD/2693 EUR) volt a férfiak és 901047 Ft (3334 USD/2826 EUR) a nők esetében.

Követheztetés: A pertrochanter törés előfordulási gyakorisága 2,5-szer magasabb a nők esetében, mint a férfiaknál. Az aktívfekvőbeteg-szakellátás igénybevétele bizonyult a legfőbb költségtényezőnek.

Orv Hetil. 2021; 162(Suppl 1): 46-53.
\end{abstract}

Kulcsszavak: pertrochanter törés, betegségteher, egészségpolitika, egészségbiztosítás, finanszírozás

\section{Annual epidemiological and health insurance disease burden of pertrochanteric fractures in Hungary}

Introduction: Health services utilization related to pertrochanteric fractures represents a significant burden for the society and health care systems.

Objective: Our aim was to analyse the epidemiological and health insurance burden of pertrochanteric fractures in Hungary.

Data and methods: Data were derived from the financial database of the National Health Insurance Fund Administration (NHIFA) of Hungary for the year 2018. The data analysed included annual patient numbers, prevalence per 100000 population in acute inpatient care, health insurance costs calculated for age groups and sex for all types of care. Patients with pertrochanteric fracture were identified with the code S7210 of the International Classification of Diseases, 10th revision.

Results: We found a significant patient turnover in outpatient care: 2845 men, 6312 women, in total 9157 patients, followed by acute inpatient care ( 2388 men, 5858 women, together: 8246 patients). Based on patient numbers in acute inpatient care, the prevalence per 100000 among men was 51.1, among women 114.7, together 84.3 patients. 
In 2018, NHIFA spent 7.329 billion HUF (27.12 million USD, 22.98 million EUR) on the treatment of pertrochanteric fractures. $28.0 \%$ of the costs was spent on the treatment of male, $72.0 \%$ on female patients. Reimbursement of acute inpatient care was the main cost driver (90.7\% of the total expenditure). The average annual treatment cost per patient was 858710 HUF (3177 USD/2693 EUR) for men and 901047 HUF (3334 USD/2826 EUR) for women.

Conclusion: The prevalence of pertrochanteric fracture was 2.5 times higher in women compared to men. Acute inpatient care was the major cost driver in the treatment of pertrochanteric fracture.

Keywords: pertrochanter fracture, disease burden, health policy, health insurance, financing

Gazsó T, Elmer D, Endrei D, Sebestyén A, Kajos LF, Wiegand N, Boncz I. [Annual epidemiological and health insurance disease burden of pertrochanteric fractures in Hungary]. Orv Hetil. 2021; 162(Suppl 1): 46-53.

(Beérkezett: 2021. január 4.; elfogadva: 2021. január 25.)

\section{Rövidítések}

BNO = Betegségek Nemzetközi Osztályozása; CT = (computed tomography) komputertomográfia; DHS $=($ dynamic hip screw) dinamikus csípőcsavar; MRI = (magnetic resonance imaging) mágnesesrezonancia-képalkotás; NEAK = Nemzeti Egészségbiztosítási Alapkezelő; PET = pozitronemissziós tomográfia

A vizsgált adatok vonatkozásában a combcsont proximális végének törései jelentik az egyik leggyakoribb diagnózist a fekvő betegek kórházi kezelésében, és a társadalom demográfiai változásai miatt ennek a klasszikus életkori törésnek a növekedésére kell számítani [1]. A társadalom fokozatos elöregedése világszerte egyre nagyobb népegészségügyi problémát jelez. Míg Európában a 2019. év elején 90,5 millió, 65 évesnél idősebb ember élt, addig 2050-re 130 millióra becsülik az idősebbek számát [2]. A trend Ázsiában még határozottabb: a 65 évesnél idősebbek száma 145 millióról várhatóan 894 millióra fog emelkedni [3]. A combcsont proximális végének törése mára a harmadik leggyakoribb törés lett a felnőttek körében. A népesség elöregedésével és az osteoporosis szinte népbetegséggé válásával a csípőtáji törések is egyre gyakoribbak. Ez igen komoly egészségügyi, szociális és gazdasági problémát jelent.

Ezek az idős emberek életét veszélyeztető sérülések, mert a kezelés és/vagy a rehabilitáció elégtelensége esetén a tartósan ágyban fekvő beteg a szövődmények (pneumonia, urosepsis, szívelégtelenség, thrombosis, embolia, decubitus) áldozatául esik [4-8]. Az időskori csípőtáji sérülések oka az elesés, fiatalkorban azonban a leggyakrabban nagy energiájú eróbehatás miatt keletkezik (motorizációs baleset, magasból esés). A pertrochanter törés - vagy más néven intertrochantericus törés a combnyaktörésnél gyakoribb [9]. Az osteoporosis és a vele összefüggésbe hozható csípőtáji törések kiemelkedő népegészségügyi problémát jelentenek a magas mortalitás és a csaknem minden esetben tapasztalható életminőség-romlás miatt [10].
Elemzésünk célja volt a pertrochanter törés okozta éves epidemiológiai és egészségbiztosítási betegségteher meghatározása Magyarországon.

\section{Adatok és módszerek}

Magyarországon az egészségbiztosítás kötelező és átfogó védelmet nyújt az egészségügyi kiadásokkal szemben. A törvényben előírt kötelező egészségbiztosítás alapján egyetlen egészségbiztosító múködik, melyhez Magyarország teljes lakossága kötődik. Az elemzésben felhasznált adatok a Nemzeti Egészségbiztosítási Alapkezelő (NEAK) - mint egyedüli egészségbiztosító - finanszírozási adatbázisából származnak, és a 2018. évet fedik le. Az elemzéshez bevont pertrochanter töréses betegkört a Betegségek Nemzetközi Osztályozása (BNO, 10. revízió) szerinti S7210-es kóddal azonosítottuk.

A lekérdezés során az alábbi egészségbiztosítási ellátásokat vontuk be: háziorvosi ellátás; otthoni szakápolás; járóbeteg-szakellátás, aktív- és krónikusfekvőbeteg-szakellátás; képalkotó diagnosztika (komputertomográfia [CT], mágnesesrezonancia-képalkotás [MRI], pozitronemissziós tomográfia [PET]) és laboratóriumi ellátás; gondozóintézeti gondozás; tételes elszámolás alá eső egyszer használatos eszközök, implantátumok, gyógyszerek és nagy értékű mütéti eljárások; gyógyszer- és gyógyászatisegédeszköz-ártámogatás; betegszállítás és mentés.

Az aktív- (benne a kúraszerű és az egynapos) és a krónikusfekvőbeteg-szakellátások esetében az adatlekérés a NEAK kórházi (osztályos) ápolási esetről szóló adatlapjának 26. mezőjében található diagnózisok közül a következőket vettük figyelembe: „1. ápolást indokló fódiagnózis alapjául szolgáló betegség”, illetve „3. ápolást indokló fődiagnózisok". Az elemzések során az aktív- és a krónikus-szakellátások adatai közül a „3. ápolást indokló fődiagnózis" tétel adatait elemeztük. A járóbeteg-szakellátásnál (laboratóriumi ellátás és gondozóintézeti gondozás nélkül) a BNO-t az ambuláns adatlap 26. mezőjében található diagnózisok közül az 1. helyen 
szereplő diagnózis képezte. A laboratóriumi ellátás során az ambuláns adatlap 26. mezőjében található diagnózisok közül pedig az 1 . helyen szereplő diagnózis jelentette a BNO-t. A CT-k, MRI-k esetében az adatlap 17. mezőjében található „Vizsgálat utáni diagnózis” BNOkódját vettük figyelembe. A gondozóintézeti gondozás ellátási formánál az ambuláns adatlap 26. mezőjében található diagnózisok közül az 1. helyen szereplő diagnózist használtuk. Az otthoni szakápolás tekintetében az alapbetegség-BNO-t, a betegszállításban az adatlap 21. mezőjében található, a szállítás indokául szolgáló BNO-t, a mentés esetében a 6. mezőben található, „a mentés indokául szolgáló diagnózis”-t, míg a háziorvosi ellátásban az ellátás oka diagnózis BNO-kódját kértük le. A tételes elszámolás alá eső egyszer használatos eszközök, implantátumok, gyógyszerek és nagy értékú mütéti eljárások az adatlap 16. mezójében található „az eszköz felhasználását/az elvégzett beavatkozást indikáló diagnózis" BNO-kódja szerint, míg a tételes elszámolású gyógyszerek az adatlap 11. mezőjében található „a beavatkozást/kezelést indikáló diagnózis” BNO-kódja szerint kerültek lekérdezésre.

A NEAK egyedi adatokból aggregált adatokat szolgáltatott számunkra a NEAK adatvédelmi szabályainak megfelelően. Etikai jóváhagyás a jelen kutatáshoz nem volt szükséges.

Az epidemiológiai betegségteher vizsgálata során - első lépésként - meghatároztuk az éves betegszámokat és a 100000 lakosra jutó igénybevételi prevalenciát korcsoportos és nemenkénti bontásban. Az éves betegszám és a 100000 före eső prevalencia kiszámításakor az aktívfekvőbeteg-szakellátás során lejelentett adatokat vet- tük figyelembe az egyes kasszák közötti duplikáció elkerülése végett, tekintettel arra, hogy a pertrochanter törés kezelése minden esetben fekvőbeteg-ellátást igényel. A prevalencia kiszámításához a Központi Statisztikai Hivatalnak a magyarországi lakónépességre vonatkozó 2018. évi adatbázisát vettük alapul. Az egészségbiztosítási betegségteher vizsgálata során pedig meghatároztuk az egészségbiztosítási kiadásokat és a költségek megoszlását korcsoportos és nemenkénti bontásban. A teljes egészségbiztosítási kiadást és az egy főre eső egészségbiztosítási kiadásokat USD-ban $(270,25 \mathrm{Ft} / \mathrm{USD})$ és EUR-ban $(318,87 \mathrm{Ft} / \mathrm{EUR})$ is a Magyar Nemzeti Bank 2018. évi éves átlagárfolyamán adtuk meg. A PET nem diagnosztikája a pertrochanter töréseknek, így ebben a kasszában ellátás jelentése nem történt. A gondozóintézeti gondozás és a tételes elszámolás alá eső eszközök, implantátumok, gyógyszerek, mútéti eljárások tekintetében 1-1 beteg ellátása merült fel. A mentés kasszai vonatkozásában költségadatok nem álltak rendelkezésünkre. A magyar egészségügyi rendszer felépítésének, múködésének és finanszírozásának részletes leírása máshol megtalálható [11-17].

\section{Eredmények}

A pertrochanter törés éves betegszámait és egészségbiztosítási költségeit az 1. táblázat összegzi ellátási formánként/kasszánként. A legnagyobb országos betegszámot az ellátási forma szerint 2018-ban a járóbeteg-szakellátás esetében találtuk: 2845 férfi, 6312 nő (együtt 9157 fö). Ezt követte az aktívfekvőbeteg-szakellátás (2388 férfi és

1. táblázat | Betegszámok és egészségbiztosítási kiadások pertrochanter törésre vonatkozóan ellátási formánként (NEAK, 2018)

\begin{tabular}{|c|c|c|c|c|c|c|}
\hline \multirow{2}{*}{$\begin{array}{l}\text { Ellátási forma } \\
\text { (NEAK-kassza) }\end{array}$} & \multicolumn{3}{|c|}{ Betegszám (fó) } & \multicolumn{3}{|c|}{ Kiadás (Ft) } \\
\hline & Férfi & Nő & Együtt & Férfi & Nő & Együtt \\
\hline Háziorvosi ellátás & 1699 & 3735 & 5434 & 4250147 & 7613203 & 11863350 \\
\hline Otthoni szakápolás & 408 & 1123 & 1531 & 25060803 & 68354947 & 93415750 \\
\hline Betegszállítás & 1513 & 3860 & 5373 & 25319380 & 59526973 & 84846353 \\
\hline Mentés & 95 & 208 & 303 & 0 & 0 & 0 \\
\hline Járóbeteg-szakellátás & 2845 & 6312 & 9157 & 18605997 & 37326272 & 55932269 \\
\hline Gondozóintézeti gondozás & 0 & 1 & 1 & 0 & 61361 & 61361 \\
\hline Laboratóriumi diagnosztika & 411 & 927 & 1338 & 650040 & 1511844 & 2161884 \\
\hline CT, MRI & 206 & 387 & 593 & 3278448 & 6167961 & 9446409 \\
\hline PET & 0 & 0 & 0 & 0 & 0 & 0 \\
\hline Aktívfekvőbeteg-szakellátás & 2388 & 5858 & 8246 & 1866056951 & 4783857463 & 6649914414 \\
\hline Krónikusfekvőbeteg-szakellátás & 566 & 1610 & 2176 & 88866360 & 261089400 & 349955760 \\
\hline $\begin{array}{l}\text { Tételes elszámolás alá eső eszközök, implantátumok, } \\
\text { gyógyszerek, mútéti eljárások }\end{array}$ & 1 & 0 & 1 & 384 & 0 & 384 \\
\hline Gyógyszer-ártámogatás & 420 & 1029 & 1449 & 1106244 & 2415533 & 3521777 \\
\hline Gyógyászati segédeszközök ártámogatása & 1047 & 2795 & 3842 & 17405560 & 50411257 & 67816817 \\
\hline Összesen & - & - & - & 2050600313 & 5278336214 & 7328936528 \\
\hline
\end{tabular}

$\mathrm{CT}$ = komputertomográfia; MRI = mágnesesrezonancia-képalkotás; NEAK = Nemzeti Egészségbiztosítási Alapkezelő; PET = pozitronemissziós tomográfia 


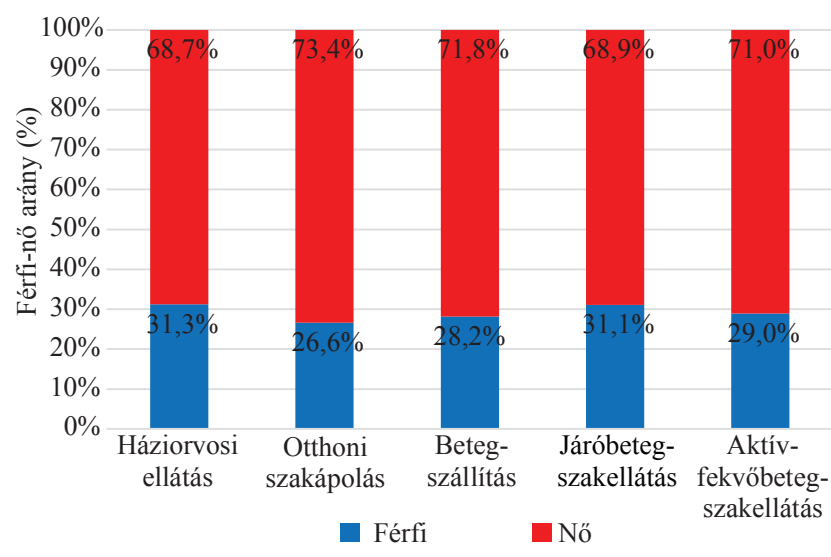

1. ábra

A pertrochanter törés egészségbiztosítási kiadásainak megoszlása nemek szerinti bontásban a fóbb ellátási formák tekintetében (NEAK, 2018

NEAK = Nemzeti Egészségbiztosítási Alapkezelő

5858 nő, együtt 8246 fó) és a háziorvosi ellátás (1699 férfi, 3735 nő, együtt 5434 fó).

A betegek nemek közti megoszlását nézve a legnagyobb betegforgalmú ellátási formákban azt tapasztaltuk, hogy egységesen jelentősen magasabb volt a női betegek aránya: a járóbeteg-szakellátásban $31,1 \%$ férfi és $68,9 \%$ nő, az aktívfekvőbeteg-szakellátásban $29,0 \%$ férfi és $71,0 \%$ nő, a háziorvosi ellátásban $31,3 \%$ férfi és $68,7 \%$ nő volt a megoszlási arány (1. ábra).

Az ellátások kor és nem szerinti igénybevételének vizsgálatakor azt tapasztaltuk, hogy a kor elörehaladtával mindkét nem esetében nőtt az esetek száma, a nók körében a növekedés mértéke jelentős. Az aktívfekvőbetegszakellátás esetében a nőknél a legfiatalabb (0-19 év) korcsoportban 6 beteget, a 20-29 éves korcsoportban 5 fót, a 30-39 éveseknél 23 föt, a 40-49 éveseknél 77 föt, az 50-59 éveseknél 382 fơt, a 60-69 éveseknél 1086 föt, míg a 70 év felettiek esetében 4279 főt jelentettek le. A férfiak száma minden korcsoportban jelentősen alacsonyabb volt: 8 fó, 18 fó, 63 fó, 157 fó, 515 fó, 576 fó, 1051 fö. A férfiak esetében a 20-60 éves korcsoportban a nők esetszámaihoz viszonyított magasabb esetszám okaként a kockázatviselő magatartás, a gyakoribb motorizációs balesetekben való részvétel említhető meg. A korcsoportos elemzés alapján megállapítható, hogy a férfiak esetében 40 év felett, míg a nók esetében 50 év felett kezdett emelkedni a betegszám. A 70 év feletti nók kiugróan magas betegszáma az összes nói beteg 73,0\%át, illetve mindkét nem összes betegszámának 51,9\%-át jelentette (2., 3. ábra).

Megállapítottuk továbbá az aktívfekvőbeteg-szakellátás betegforgalmi adatai alapján, hogy a 100000 före eső pertrochanter törés prevalenciája férfiaknál 51,1 fó, nőknél 114,7 fó, együtt 84,3 fó volt Magyarországon a 2018. évben. Az aktívfekvőbeteg-szakellátás betegforgalmi adatai alapján a férfiak átlagéletkora 72,8 év, míg a nóké 81,1 év volt, együtt 78,7 év.

A pertrochanter törés kezelésére a NEAK 7,329 milliárd Ft-ot költött 2018-ban, ami 27,12 millió USD-nak, illetve 22,98 millió EUR-nak felel meg. A NEAK különböző kiadási tételei az ellátási formák között jelentős eltérést mutatnak az aktívfekvőbeteg-szakellátás eltolódásának irányába. A legnagyobb kiadási tételt a kórkép esetében - sorrendben haladva - az aktívfekvőbetegszakellátásnál (6 649914414 Ft; 90,7\%), a krónikusfekvőbeteg-szakellátásnál (349 $955760 \mathrm{Ft} ; 4,8 \%$ ) és az otthoni szakápolásnál (93 $415750 \mathrm{Ft} ; 1,3 \%)$ találtuk (4. ábra).

A kiadások nemek közti megoszlását nézve a legmagasabb kiadású ellátási formákon belül azt tapasztaltuk, hogy a költségek a következő arányokban oszlottak meg: aktívfekvőbeteg-szakellátás: $28,1 \%$ férfi és $71,9 \%$ nő;

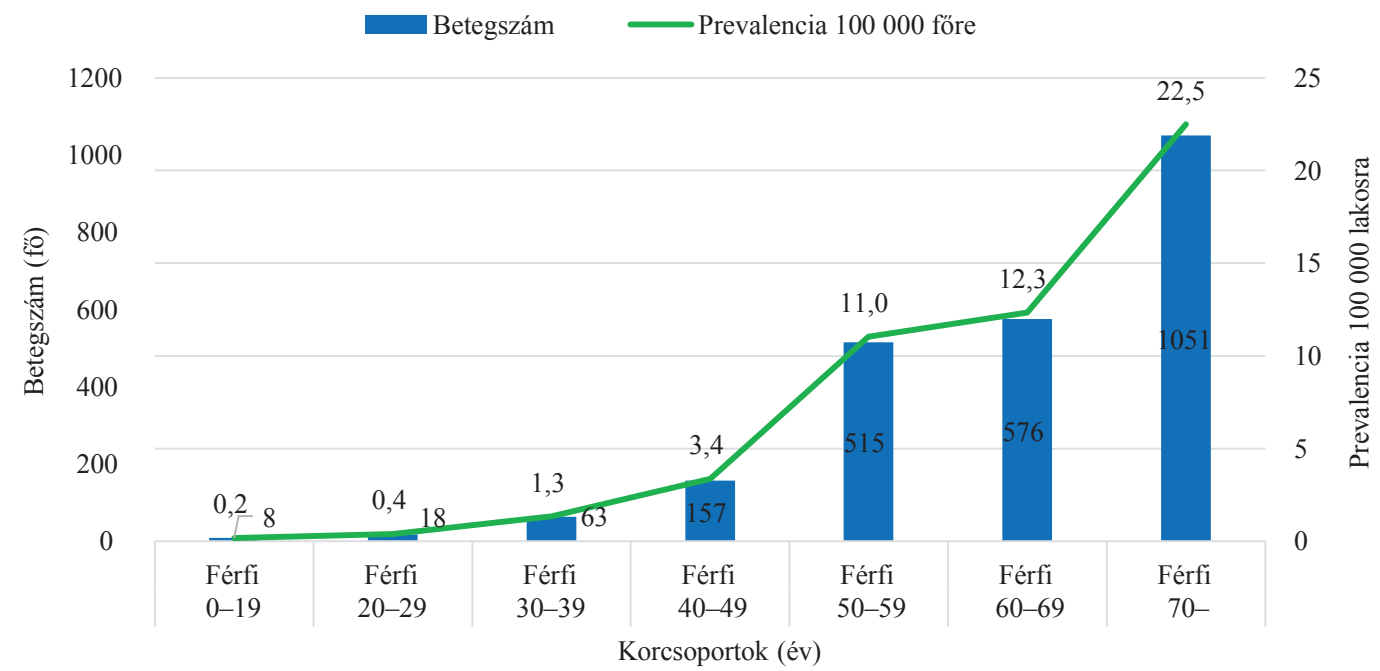

2. ábra

Az aktívfekvőbeteg-szakellátás keretében ellátott pertrochanter törésből eredő megbetegedések száma és 100000 lakosra számított prevalenciája a férfiak körében korcsoportok szerinti bontásban (NEAK, 2018)

NEAK = Nemzeti Egészségbiztosítási Alapkezelő 


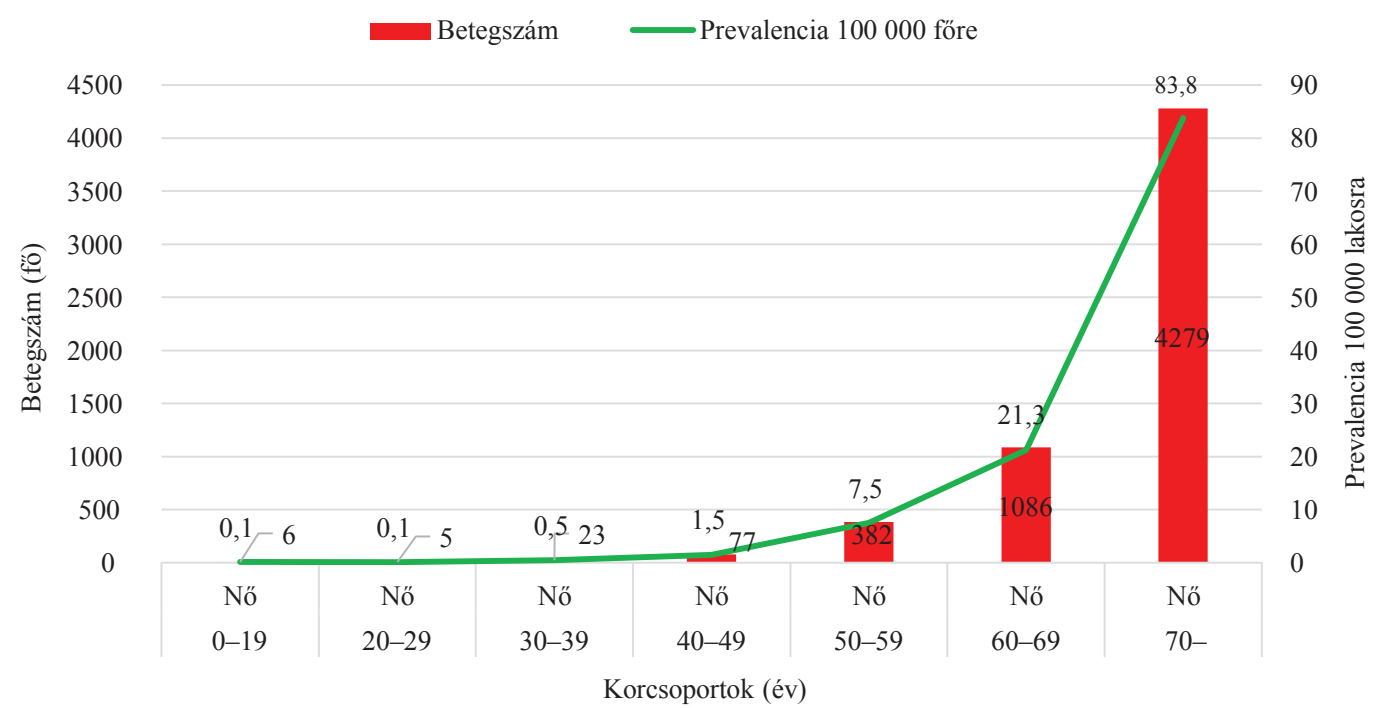

3. ábra

Az aktívfekvőbeteg-szakellátás keretében ellátott pertrochanter törésből eredő megbetegedések száma és 100000 lakosra számított prevalenciája a nók körében korcsoportok szerinti bontásban (NEAK, 2018)

NEAK = Nemzeti Egészségbiztosítási Alapkezelő

krónikusfekvőbeteg-szakellátás: 25,4\% férfi és 74,6\% nő; otthoni szakellátás: szintén $26,8 \%$ férfi és $73,2 \%$ nő. A kiadások 28,0\%-a férfiaknál, míg 72,0\%-a nóknél jelent meg.

A NEAK összkiadásait nézve azt tapasztaltuk, hogy az aktívfekvőbeteg-szakellátás (a teljes egészségbiztosítási kiadás 91,0\%-a férfiaknál és 90,6\%-a nőknél), a krónikusfekvőbeteg-szakellátás (4,3\% férfiaknál és 4,9\% nőknél) és az otthoni szakellátás (1,2\% férfiaknál és 1,3\% nóknél) voltak a meghatározó költségelemek, míg az összes többi egészségügyi ellátási forma részesedése a férfiaknál $3,5 \%$, a nőknél $3,1 \%$ volt.

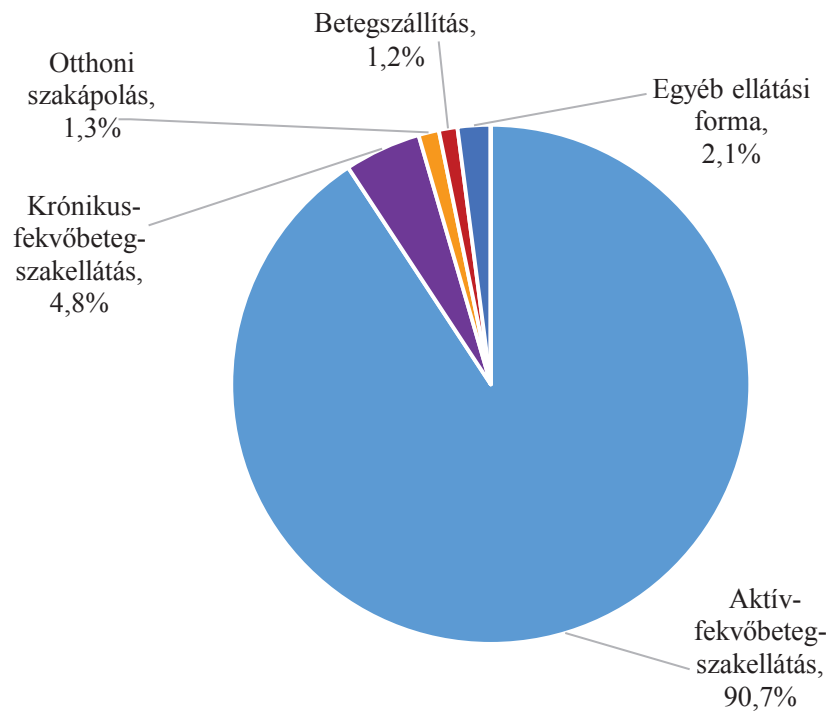

4. ábra

A pertrochanter törés kezelésére fordított egészségbiztosítási kiadások megoszlása az egyes ellátási formák tekintetében (NEAK, 2018

NEAK = Nemzeti Egészségbiztosítási Alapkezeló
A legnagyobb költségű aktívfekvőbeteg-szakellátási kassza kor és nem szerinti igénybevételének vizsgálatakor azt láttuk, hogy a nők esetében jelentős mértékben emelkedett az összkiadások mértéke a kor előrehaladtával, különösen a 70 év feletti korosztályban. A férfiak esetében mérsékeltebb ugyan, de folyamatos a növekedés, nem jelentkezik kiugró emelkedés, de szintén a 70 év feletti korosztályban tetőzik a kiadás. A 70 év feletti nők kiugróan magas kiadásai (3,837 milliárd Ft) az összes női beteg kiadásának 72,7\%-át, illetve mindkét nem összes kiadásának 52,4\%-át jelenti (5. ábra).

Megállapítottuk továbbá, hogy a NEAK az összkiadásai (férfiak, nők) 95,9\%-át (7 028069807 Ft) az 50 év feletti korosztályra, 85,2\%-át (6 247411364 Ft) a 60 év feletti korosztályra, 64,8\%-át (4 746436509 ) pedig a 70 év feletti korosztályra költötte. A 70 év feletti korosztály esetében a nők kiemelkedően magas arányban, 80,8\%-ban vették ki részüket a korcsoportos kiadásokból, a 60-69 éves korosztályban 66,7\%-ban, míg az 5059 éves korosztályban csak 43,9\%-ban.

Végül összegeztük, hogy 2018-ban a pertrochanter törés miatt kezelt egy betegre jutó átlagos összesített éves egészségbiztosítási kiadás $888 \quad 787$ Ft (3289 USD/2787 EUR) volt összesen; a férfiak esetében 858710 Ft (3177 USD/2693 EUR), a nők esetében pedig $901047 \mathrm{Ft}$ (3334 USD/2826 EUR).

\section{Megbeszélés}

A pertrochanter törés az idősek egyik leggyakoribb sérülése, és a demográfiai változások miatt ennek a törésnek az előfordulása és jelentősége a jövőben még növekedni fog [18]. Tanulmányunkban az S7210-es BNO-kódú pertrochanter törés okozta, országos szintú epidemiológiai és egészségbiztosítási betegségteher vizsgálatát vé- 


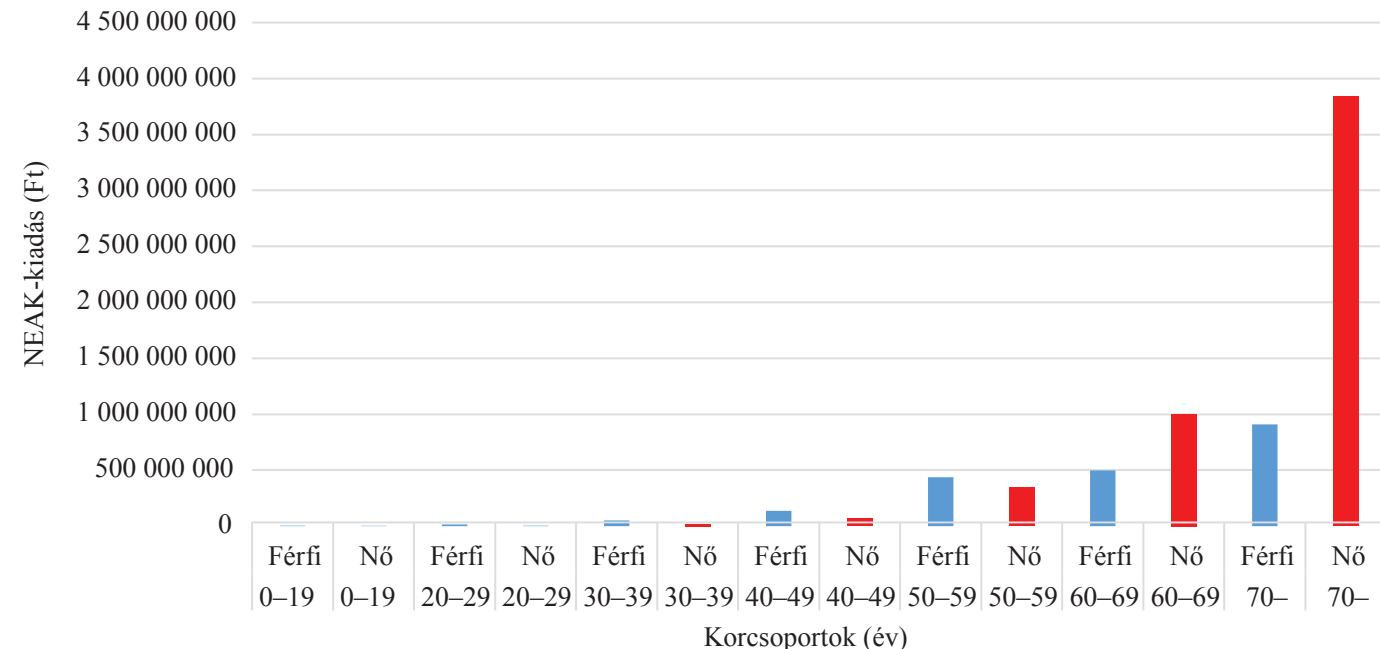

5. ábra

A pertrochanter törés összes egészségbiztosítási kiadásának megoszlása korcsoportok és nemek szerint (NEAK, 2018)

NEAK = Nemzeti Egészségbiztosítási Alapkezelő

geztük el a 2018-as évre vonatkozólag. A közép-keleteurópai régióról - így Magyarországról is - nagyon korlátozottan állnak rendelkezésre epidemiológiai- és költségadatok a pertrochanter törés vonatkozásában [19, 20], a combnyaktörésekkel ellentétben [21, 22]. Kutatásunk az első olyan, országos szintű elemzés, amely a társadalmi és a gazdasági teher oldaláról is megvizsgálja a pertrochanter törést valamennyi egészségbiztosítási kassza tekintetében, kor és nem szerinti bontásban.

Az elemzésben vizsgált betegség 2018. évi magyarországi prevalenciája 100000 före vetítve - az aktívfekvőbeteg-szakellátás alapján - 51,1 fó volt a férfiaknál, 114,7 fó a nőknél, együtt 84,3 fó. A NEAK a 2018. évben 7,329 milliárd Ft-ot költött az érintett ellátásokra, ami 27,12 millió USD-nak, illetve 22,98 millió EUR-nak felelt meg. A kiadások nagyobb aránya $(72,0 \%)$ a nőknél jelent meg, és az aktívfekvőbeteg-szakellátás bizonyult a legmeghatározóbb költségelemnek. Az egy betegre jutó átlagos éves egészségbiztosítási kiadás 888787 Ft (3289 USD/2787 EUR) volt. A 70 év feletti nők esetében igen magas, 3837226477 Ft volt a kifizetett összeg, ez a teljes kiadás 52,4\%-nak felelt meg. A 70 év feletti nók esetében az egy betegre jutó kiadás $896758 \mathrm{Ft}$ volt, amely nem mutat szignifikáns eltérést az eltérő korcsoportok összesített adataitól. A 70 év felett hirtelen megemelkedő kiadásokat a betegszámok érintett korosztályos emelkedése okozta. Az életkor előrehaladtával növekvő betegszámot és a nemek közötti különböző növekedési rátákat Lamb és mtsai [23] angliai kutatása (916 beteg alapján) is alátámasztotta: megállapították, hogy a nők körében a pertrochanter törések relatív előfordulása az életkor előrehaladtával a 30 és a 70 éves korosztály között a kétszeresére növekedett. Az angliai kutatás nagyon hasonló eredményt hozott a nók betegszámának 72,7\%-os arányával és 83,5 éves átlagéletkorával (saját elemzésünkben a nők aránya 71,0\%, átlagélet- koruk 81,1 év volt), míg az angol férfiak átlagéletkora 77,8 év volt - saját elemzésünk kissé alacsonyabb, 72,8 évet állapított meg. A nóknél tapasztalt magasabb betegszám oka, hogy az érintett, idősebb korosztályba tartozó nők magas százaléka már osteoporosisban és egyéb gyakori krónikus betegségben (például koordinációzavar) is szenved, ezért hajlamosabbak a törésre.

Nemzetközi összehasonlításban elmondhatjuk, hogy a pertrochanter törésnek a magyar lakosság körében becsült prevalenciája 100000 före vonatkoztatva $(84,3)$ nagyságrendileg a Glinkowski és mtsai [24] szakirodalmi kutatásaiban talált lengyelországi 2008. évi (73) prevalenciához hasonlítható, de alulmarad a 2015. évi (237) prevalenciához képest. Az aktívfekvőbeteg-szakellátás kasszája alapján megállapítottuk, hogy a férfiaknál 40 év felett, míg a nóknél 50 év felett kezdett emelkedni a betegszám, és a nők körében nagyobb (71\%) volt a betegség előfordulási aránya - így hasonló megállapításra jutottunk, mint több nemzetközi tanulmány $[25,26]$.

Az egészségbiztosítási költségteher tekintetében a külföldi - kiemelten az Amerikai Egyesült Államokban készült - tanulmányok magasabb, egy betegre jutó átlagos éves egészségbiztosítási kiadásokat állapítottak meg. Lindvall és mtsai [27] vizsgálatában (609 beteg, 3 kórház) az egy betegre eső átlagos kiadás 14268 és 20184 USD között volt, míg Patterson és mtsai [28] az amerikai veteránok ellátási költségét 26955 és 30020 USD között határozták meg.

Hazánkban Sebestyén és mtsai a combnyaktörések mortalitását és kockázati tényezőit ötéves utánkövetéssel vizsgáló tanulmányukban a primer ellátást követő első hónapban 8,99\%-os, az első évben 30,74\%-os, öt év alatt 61,88\%-os halálozásról számoltak be [29]. A combnyaktörést követő 30 napos halálozás szignifikáns kockázati tényezői közül kiemelkedik az időskor, a férfinem és a kísérő betegségek $[30,31]$. A combnyaktörések ellátásá- 
hoz kapcsolódó kórházi költségek elemzésének hazánkban kiterjedt irodalma van [32].

Az utóbbi 50 évben a pertrochanter törések terápiájában óriási fejlődés ment végbe: a nagy feltárásos, sok vérveszteséggel járó, legfeljebb mozgásstabil szintézisek alkalmazásától (toldalékos combnyakszegezés, Ender-szegezés, szögletlemezes szintézis) a kisebb feltárással járó, nagyobb terhelést megengedő DHS- (dynamic hip screw) szintézisnek, valamint a minimálinvazív terhelésstabil gamma-szegezéseknek az alkalmazásáig.

Kutatásunk időintervalluma egy év időszakát fedi le, így nem vonhatók le következtetések a tendenciákat illetően. A hazai prevalenciaadatok kiszámítása - az egészségbiztosítási elszámolási kasszák közötti átfedések elkerülésének és a torzítás minimálisra való leszorításának érdekében - a NEAK-nak az aktívfekvőbeteg-szakellátásra vonatkozó adataiból történt.

Adatelemzésünk eredményeit tekintve fontos tényező, hogy a NEAK által szolgáltatott adatok az egyetlen országos és teljes körú forrásunkat képezik; nem létezik alternatív adatrendszer, például combnyaktörés-regiszter, így jelenleg csak a NEAK-adatok elemzése adhat számunkra átfogó országos képet az epidemiológiai és egészségbiztosítási költségekről.

Országos szintű reprezentatív felmérésünk hiánypótló jelentőségû́ a pertrochanter törések témakörében, mivel ezen törések kiemelkedően magas egészségügyi, szociális és társadalmi terhet jelentenek, valamint a kevés, rendelkezésre álló hazai adat és kutatás is indokolttá teszi vizsgálatát epidemiológiai és egészségbiztosítási szempontból is. Kutatásunk az egészségügyi ellátórendszer és a társadalom számára fontos adatokat mutat be, melyek segítséget nyújthatnak az egészségpolitikai döntéshozatalban, a társadalombiztosítási döntések előkészítésében, valamint az ellátási és prevenciós stratégiák megalkotásában.

Anyagi támogatás: A kézirat az „EFOP-3.6.2-16-201700009: Klinikai kutatások tematikus hálózatának kialakítása és nemzetköziesítése” projekt keretében az „Egészségbiztosítási és klinikai real-world adatvagyon hasznosítása” alprojekt támogatásával készült.

Szerzői munkamegosztás: A vizsgálat tervezése és lefolytatása: G. T., En. D., B. I. Adatok gyüjtése és ellenőrzése: G. T., El. D., B. I. Adatfeldolgozás és adatelemzés: G. T., S. A. Statisztikai elemzések: G. T. Irodalomkutatás: G. T., El. D., B. I., K. L. F., W. N. A kézirat megszövegezése: G. T., El. D., En. D., S. A., K. L. F., W. N., B. I. A cikk végleges változatát valamennyi szerző elolvasta és jóváhagyta.

Érdekeltségek: A szerzőknek nincsenek érdekeltségeik.

\section{Köszönetnyilvánítás}

A szerzők köszönetet mondanak az „EFOP-3.6.2-16-2017-00009: Klinikai kutatások tematikus hálózatának kialakítása és nemzetköziesítése" projekt keretében nyújtott támogatásért (szakmai vezető: prof. dr. Kovács L. Gábor, a Magyar Tudományos Akadémia rendes tagja).

\section{Irodalom}

[1] Müller M, Seitz A, Besch L, et al. Proximal femur fractures. Results and complications after osteosynthesis with PFN and TGN [Versorgung pertrochantärer Femurfrakturen. Vergleichende Analyse mit PFN vs. TGN.] Unfallchirurg 2008; 111: 71-78. [German]

[2] Eurostat: Statistics Explained. Ageing Europe - looking at the lives of older people in the EU; 2020 edition. Statistical books (cat. number: KS-02-20-655-EN-N). Publications Office of the European Union, Luxembourg, 2020.

[3] Cooper C, Campion G, Melton LJ 3rd. Hip fractures in the elderly: a world-wide projection. Osteoporosis Int. 1992; 2: 285289.

[4] Professional College of Traumatology. Professional protocol of the Ministry of Health. Fracture of the femoral body in adulthood - fractura diaphyseos femoris. [Traumatológiai Szakmai Kollégium. Az Egészségügyi Minisztérium szakmai protokollja. A combcsont testének felnőttkori törése.] Egészségügyi Minisztérium, Budapest, 2008. [Hungarian]

[5] Jang SY, Cha YH, Kim KJ, et al. The effect of surgery type on mortality in elderly patients with pertrochanteric femoral fracture: a Korean nationwide cohort study. Asian J Surg. 2020; 43: $550-556$.

[6] Gomez M, Marc C, Talha A, et al. Fast track care for pertrochanteric hip fractures: how does it impact length of stay and complications? Orthop Traumatol Surg Res. 2019; 105: 979-984.

[7] Schulz C, Büchele G, Peter RS, et al. Regional variation of care dependency after hip fracture in Germany: a retrospective cohort study using health insurance claims data. PLoS ONE 2020; 15: e0230648.

[8] Dudkiewicz I, Burg A, Salai M, et al. Gender differences among patients with proximal femur fractures during rehabilitation. Gend Med. 2011; 8: 231-238.

[9] Gaál Cs. Surgery. [Sebészet.] Medicina Könyvkiadó, Budapest, 2012. [Hungarian]

[10] Rehabilitation Vocational College. Methodological letter from the Ministry of Health on the medical rehabilitation of the elderly after hip fractures. [Rehabilitációs Szakmai Kollégium. Az Egészségügyi Minisztérium módszertani levele az időskorúak orvosi rehabilitációjáról csípőtáji törések után.] Egészségügyi Minisztérium, Budapest, 2008. [Hungarian]

[11] Boncz I, Sebestyén A. Financial deficits in the health services of the UK and Hungary. Lancet 2006; 368: 917-918.

[12] Boncz I, Evetovits T, Dózsa Cs, et al. The Hungarian Care Managing Organization Pilot Program. Value Health Reg Issues 2015; 7: 27-33.

[13] Varga V, Boncz I, Sebestyén A, et al. Utilization indicators of balneotherapy in Hungary. [A gyógyfürdőellátások igénybevételi mutatói Magyarországon.] Orv Hetil. 2019; 160(Suppl 1): 2228. [Hungarian]

[14] Boncz I, Vajda R, Ágoston I, et al. Changes in the health status of the population of Central and Eastern European countries between 1990 and 2010. Eur J Health Econ. 2014; 15(Suppl 1): S137-S141.

[15] Endrei D, Molics B, Ágoston I. Multicriteria decision analysis in the reimbursement of new medical technologies: real-world experiences from Hungary. Value Health 2014; 17: 487-489. 
[16] Eisingerné Balassa B, Csákvári T, Ágoston I. Health insurance pharmaceutical expenditures in Hungary. [Az egészségbiztosítási gyógyszerkiadások alakulása Magyarországon.] Orv Hetil. 2019; 160(Suppl 1): 49-54. [Hungarian]

[17] Boncz I, Nagy J, Sebestyén A, et al. Financing of health care services in Hungary. Eur J Health Econ. 2004; 5: 252-258.

[18] Sandmann GH, Biberthaler P. Pertrochanteric femoral fractures in the elderly. [Pertrochantäre Femurfrakturen beim geriatrischen Patienten.] Unfallchirurg 2015; 118: 447-460. [German]

[19] Sebestyén, A, Gacs B, Tóth, F, et al. Global cost-effectiveness study of trochantereal fractures. [Trochantertáji törések globális költséghatékonysági vizsgálata.] Magy Traumatol Ortop Kézseb Plaszt Seb. 2000; 43: 57-63. [Hungarian]

[20] Sebestyén, A, Boncz, I, Dózsa, Cs, et al. Cost analysis of pertrochanter fractures according to the type of surgical treatment and progressivity from the point of view of purchaser. [Trochantertáji törések ellátásának költségvizsgálata a mútéti eljárások és a progresszív ellátási szintek szerint finanszírozói szemszögből.] Orv Hetil. 2004; 145: 1115-1121. [Hungarian]

[21] Sebestyén A. Investigation of the disease burden of femoral neck fracture by integrating medical, public health, and financial aspects. Doctoral dissertation. [A combnyaktörés betegség-teher vizsgálata orvosszakmai, népegészségügyi és finanszírozói szempontok integrálásával. Doktori értekezés.] Pécsi Tudományegyetem, Egészségtudományi Kar, Egészségtudományi Doktori Iskola, Pécs, 2007. [Hungarian]

[22] Sebestyén A, Péntek M, Gulácsi L, et al. Disease burden modeling of femoral neck fractures from a financier perspective. [A combnyaktörések betegségteher-modellezése finanszírozói szemszögből.] Ca\&Csont 2009; 12: 108-117. [Hungarian]

[23] Lamb JN, Panteli M, Pneumaticos SG, et al. Epidemiology of pertrochanteric fractures: our institutional experience. Eur J Trauma Emerg Surg. 2014; 40: 225-232.

[24] Glinkowski W, Narloch J, Krasuski K, et al. The increase of osteoporotic hip fractures and associated one-year mortality in Poland: 2008-2015. J Clin Med. 2019; 8: 1487.

[25] Huttunen TT, Kannus P, Pihlajamäki H, et al. Pertrochanteric fracture of the femur in the Finnish National Hospital Discharge
Register: validity of procedural coding, external cause for injury and diagnosis. BMC Musculoskelet Disord. 2014; 15: 98.

[26] Chmielnicki M, Prokop A. Pertrochanteric femur fracture - our technique and results. [Pertrochantäre Femurfraktur - Technik und eigene Ergebnisse.] Z Orthop Unfall. 2015; 153: 137-140. [German]

[27] Lindvall E, Ghaffar S, Martirosian A, et al. Short versus long intramedullary nails in the treatment of pertrochanteric hip fractures: incidence of ipsilateral fractures and costs associated with each implant. J Orthop Trauma 2016; 30: 119-124.

[28] Patterson JT, Takemoto SK, Shearer DW, et al. Does implant choice affect the episode cost of pertrochanteric hip fracture for US veterans? J Orthop Trauma 2019; 33: 635-641.

[29] Sebestyén, A, Boncz, I, Tóth, F, et al. Evaluation of the correlation between risk factors and mortality in elderly patients with femoral neck fracture with 5-year follow-up. [Időskori combnyaktöréseket követő halálozás és kockázati tényezőik kapcsolatának értékelése 5 éves utánkövetéssel.] Orv Hetil. 2008; 149: 493-503. [Hungarian]

[30] Sebestyén A, Boncz I, Sándor J, et al. Effect of surgical delay on early mortality in patients with femoral neck fracture. Int Orthop. $2008 ; 32: 375-379$.

[31] Sebestyén A, Boncz I, Sándor J, et al. Response to an article in the June 2006 issue of Medical Care. Letters to the Editor. Med Care 2006; 44: 1148-1149.

[32] Sebestyén A, Boncz I, Nyárády J. Analysis of health insurance costs in patients with medial femoral neck fractures under 60 years of age treated primarily with screw osteosynthesis or prosthesis implantation. [Az egészségbiztosítási költségek elemzése az elsődlegesen csavaros osteosynthesissel, illetve protézisbeültetéssel kezelt 60 évesnél fiatalabb medialis combnyakktörést szenvedett betegek eseteiben.] Orv Hetil. 2006; 147: 1129-1135. [Hungarian]
(Gazsó Tibor, Pécs, Vörösmarty u. 3., 7621 e-mail: gazso.tibor@pte.hu)

A cikk a Creative Commons Attribution 4.0 International License (https://creativecommons.org/licenses/by/4.0/) feltételei szerint publikált Open Access közlemény, melynek szellemében a cikk bármilyen médiumban szabadon felhasználható, megosztható és újraközölhető, feltéve, hogy az eredeti szerző és a közlés helye, illetve a CC License linkje és az esetlegesen végrehajtott módosítások feltüntetésre kerülnek. (SID_1) 